\title{
GAMBARAN BERPIKIR KRITIS DALAM PENGAMBILAN KEPUTUSAN PADA PELAKSANAAN KEPERAWATAN
}

\author{
Nadia Febriani Br.Barus \\ nadiafebriani001@gmail.com
}

Latar Belakang: gambaran berpikir kritis dalam pengambilan keputusan pada pelaksanaan keperawatan sangat diperlukan dalam keperawatan. Peningkatan kemampuan berpikir kritis akan meningkatkan kualitas asuhan keperawatan. Berfikir meliputi proses yang tidak statis, berubah setiap saat. Berfikir kritis dalam keperawatan adalah komponen dasar dalam pertanggunggugatan profesional dan kualitas asuhan keperawatan. Berpikir kritis merupakan jaminan yang terbaik bagi perawat mencapai sukses dalam berbagai aktifitas dan merupakan suatu penerapan profesionalisme serta pengetahuan tekhnis atau keterampilan tekhnis dalam memberikan asuhan keperawatan. Proses berpikir kritis meliputi memahami, mengevaluasi, mempertanyakan maupun menjawab, membangun pertanyaan yang merupakan pemicu proses berkelanjutan untuk mencari jawaban dngan kemungkinan ada jawaban atau tidak terdapat jawaban. Ada 4 hal pokok penerapan berfikir kritis dalam keperawatan, yaitu:

\section{Penggunaan bahasa dalam keperawatan}

Berfikir kritis adalah kemampuan menggunakan bahasa secara reflektif. perawat menggunakan bahasa verbal dan nonverbal dalam mengekspresikan idea, fikiran, info, fakta, perasaan, keyakinan dan sikapnya terhadap klien, sesama perawat, profesi. Secara nonverbal saat melakukan pedokumentasian keperawatan.

\section{Argumentasi dalam keperawatan}

Sehari-hari perawat dihadapkan pada situasi harus berargumentasi untuk menemukan, menjelaskan kebenaran, mengklarifikasi isu, memberikan penjelasan, mempertahankan terhadap suatu tuntutan/tuduhan. Badman and Badman (1988) argumentasi terkait dengan konsep berfikir dalam keperawatan berhubungan dengan situasi perdebatan, upaya untuk mempengaruhi individu ataupun kelompok.

3. Pengambilan keputusan dalam keperawatan

ssSehari-hari perawat harus mengambil keputusan yang tepat. 


\section{Penerapan proses keperawatan}

Perawat berfikir kritis pada setiap langkah proses keperawatan

a. Pengkajian: mengumpulkan data, melakukan observasi dalam pengumpulan data berfikir kritis, mengelola dan mengkatagorikan data menggunakan ilmu-ilmu lain.

b. Perumusan diagnosa keperawatan: tahap pengambilan keputusan yang paling kritis, menentukan masalah dan dengan argumen yaitu secara rasional.

c. Perencanaan keperawatan: menggunakan pengetahuan untuk mengembangkan hasil yang diharapkan, keterampilan guna mensintesa ilmu yang dimiliki untuk memilih tindakan.

d. Pelaksanaan keperawatan: pelaksanaan tindakan keperawatan adalkah keterampilan dalam menguji hipotesa, tindakasn nyata yang menentukan tingkat keberhasilan.

e. Evaluasi keperawatan: mengkaji efektifitas tindakan, perawat harus dapat mengambil keputusan tentang pemenuhan kebutuhan dasar klien.

Metode :Proses keperawatan dalam pengambilan keputusan adalah suatu metode yang digunakan seorang perawat untuk membantu memecahkan masalah pasien. Berfikir adalah merupakan salah satu fungsi otak dan fungsi tersebut dapat berjalan dengan baik jika tubuh dalam keaadaan sehat dan lingkungan yang memberikan rangsangan. Hal tersebut harapannya sebagai perawat mempunyai otak yang sehat. Untuk melaksanakan proses perawatan tersebut perawat dituntut melakukan aktifitas kognitif dalam berfikir kritis,yang diperlukan beberapa komponen antara lain: Pengetahuan, Pengalaman, Kompetensi, Sikap dan Standar Berfikir kritis dalam proses keperawatan berawal dari tahap Pengkajian, Diagnosis keperawatan, Perencanaan Keperawatan, Pelaksanaan dan evaluasi yang semuanya merupakan standar praktek keperawatan professional. Perawat dalam memenuhi secara komprehensif, menggunakan ketrampilan kritis dan profesional sehingga pelayanan yang diberikan bermutu bagi pasien maupun perawat sendiri.Kemampuan berpikir kritis merupakan kemampuan sangat esensial dalam memberikan pelayanan terhadap pasien. Faktor- faktor yang dapat mempengaruhi kemampuan berpikir kritis antara lain kondisi fisik, motivasi, kecemasan, kebiasaan, perkembangan intelektual, konsistensi, perasaan, dan pengalaman. Faktor tersebut dapat memberikan dukungan positif ataupun menurunkan kemampuan berpikir kritis. Tujuan penelitian ini menganalisis faktor yang mempengaruhi penerapan keterampilan berpikir kritis perawat dalam melaksanakan asuhan keperawatan. Perkembangan intelektual perawat dapat meningkatkan berpikir kritis yang paling dominan dalam melaksanakan asuhan keperawatan. 
Hasil: Berfikir kritis dalam pengambilan keputusan pada pelaksanaan keperawatan merupakan kemampuan yang sangat mempengaruhi sikap dan prilaku dalam melaksanakan asuhan keperawatan. Yang juga merupakan metode yang wajib digunakan seorang perawat dalam membantu pasien memecahkan suatu masalah ataupun mengambil tindakan di waktu yang sesingkat singkatnya. Perlu kita ketahui bahwa berpikir kritis sangat diperlukan dalam bidang keperawsatan. Salah satunya hal yang sangat perlu diketahui sebelumnya yaitu manfaat dan fungsi berpikir kritis dalam keperawatan. Hal tersebut sangat dibutuhkan dalam keperawatan agar kita mengetahui dengan jelas untuk apa dipelajari kegunaan berpikir kritis ini. Pengkajian ini dilakukan untuk mengetahui apa manfaat dan fungsi dilakukannya berfikir kritis dalam keperawatan. Juga untuk menambah wawasan untuk pembaca dalam memahami berpikir kritis dalam keperawatan. Serta dapat menerapkan dilapangan untuk menyelesaikan sebuah masalah.

Pada literature review didapatkan hasil bahwa untuk meningkatkan cara berpikir kritis perawat dilakukan dengan menganalisis, mengkaji, mengeksplorasi berbagai bentuk bacaan demi meningkatnya sikap berpikir kritis

Berpikir kritis memiliki kaitan dalam proses pengambilan keputusan dan penilaian klinis yang akan menjadi penentu pemberian asuhan keperawatan yang berkualitas. Oleh karena itu, seorang Perawat wajib berpikir secara kritis dalam praktik keperawatannya. Tujuan : untuk mengetahui hubungan berpikir kritis dalam proses pengambilan keputusan, sehingga nantinya berguna bagi perawat karena dengan mudah untuk mengambil keputusan dalam menetapkan suatu kondisi yang dialami oleh pasien

Seorang perawat yang bekerja lebih lama akan sangat mudah dapat berpikir kritis dikarenakan belajar dari pengalaman pengalaman lalu yang didapatkannya sehingga tingkat pengetahuan juga akan meningkat, tetapi Pembelajaran, dan pengalaman tidak dapat dipisahkan karna sama sama dibutuhkan untuk mengembangkan pengetahuan dan keterampilan perawat dalam mengenali, melaporkan, dan menanggapi masalah pasien. Perawat yang selalu berpikir kritis atau kreatif akan selalu melihat dan memecahkan masalah dengan sudut pandang yang berbeda dan mempertimbangkan dengan mendalam setiap masalah yang akan diambil demi kebaikan pasien,dan diri. 


\section{Pembahasan}

Gambaran Berpikir kritis dalam keperawatan merupakan keterampilan berpikir perawat menguji berbagai alasan secara rasional sebelum mengambil keputusan dalam asuhan keperawatan.Berpikir kritis dalam asuhan keperawatan memberikan jaminan keamanan dan memenuhi standar pelayanan.Berpikir kritis merupakan suatu pengujian yang rasional terhadap beberapa ide, kesimpulan, prinsip, argumen, penjelasan, persoalan, pernyataan, keyakinan dan tindakan, serta inti dari praktik keperawatan professional.

berpikir kritis adalah suatu upaya yang dilakukan dalam memberdayakan keterampilan atau strategi kognitif untuk menentukan gambaran maupun tujuan yang diharapkan. Oleh karena itu untuk memberikan perawatan yang aman dan efektif bagi pasien dengan kebutuhan yang kompleks sangat penting bagi perawat dapat mengembangkan keterampilan berfikir kritis.

Gambaran Berfikir kritis adalah salah satu kegiatan yang memerlukan ide ide serta gagasan yang cepat dalam melakukan penilaian dan analisa rasional serta merumuskan kesimpulan dan membuat keputusan

Berpikir kritis dalam pendidikan keperawatan merupakan komponen

penting dari akuntabilitas profesional dan asuhan keperawatan berkualitas.

Berpikir menjadi bagian tak terpisahkan dari asuhan keperawatan yang dilakukan oleh perawat. Berpikir kritis penting dilakukan oleh perawat sebelum mengambil keputusan dalam asuhan keperawatan.Asuhan keperawatan merupakan satu metode ilmiah dalam penyelesaian masalah klien. Kemampuan perawat mengidentifikasi masalah klien dan memilih solusi intervensi yang tepat tidak lepas dari kemampuan perawat berpikir kritis, yaitu kemampuan perawat menggali alasan berdasarkan evidence base dari setiap problem dan solusi yang teridentifikasi. Kemampuan berpikir kritis dan disposisinya dapat digunakan ketika menyelesaikan masalah keperawatan

Kemampuan yang sangat esensial dan berfungsi dalam semua aspek kehidupan terutama dalam melaksanakan pekerjaan diperlukan kemampuan berpikir kritis agar masalah pekerjaan dapat diselesaikan dengan baik

Seorang perawat harus memiliki kemampuan untuk menggali setiap perubahan yang terjadi pada pasien, memberikan pelayanan yang mandiri, dan tanggap terhadap berbagai 
permintaan dan dapat menentukan prioritas. Hal ini tentu saja membutuhkan kemampuan berpikir kritis dan kemampuan untuk menyelesaikan masalah yang terjadi dengan baik serta dapat berkomunikasi dengan baik dan jelas.

menyebutkan gambaran berpikir kritis adalah komponen penting akuntabilitas professional dan kualitas pelayanan keperawatan. Berpikir kritis menunjukkan kepercayaan diri, kreativitas, fleksibilitas, perspektif kontekstual, integritas intelektual, intuisi, berpikir terbuka, tekun dan kemampuan merefleksikan. Dalam praktik keperawatan berpikir kritis adalah keterampilan kognitif dalam menganalisis, menerapkan standar, memilah, memperhatikan informasi/data yang ada, berpikir logis, mampu memprediksi dan mentransformasikan pengetahuan yang di miliki.

untuk Pengambilan keputusan mengenai triase yang dilakukan oleh perawat triase sangat ditentukan oleh tingkat pengetahuan triase. Berbagai metode dapat dilakukan untuk meningkat pengetahuan perawat triase. Adanya pedoman, algoritma triase, pelatihan, kaderisasi telah membuktikan dapat meningkatkan pengetahuan triase.

Berfikir kritis ini penting dilakukan sebelum mengambil keputusan dalam asuhan keperawatan karena merupakan salah satu metode ilmiah dalam menyelesaikan masalah klien. Kemampuan perawat mengidentifikasi masalah klien dan memilih solusi intervensi yang tepat tidak lepas dari kemampuan perawat berfikir kritis untuk mengali berbagai alasan berdasarkan evidence base dari setiap problem dan solusi yang teridentifikasi Untuk berfikir cerdas perawat harus mengembangkan cara berfikir kritis dalam menghadapi setiap masalah dan pengalaman baru yang menyangkut pasien dengan memiliki karakteristik percaya diri, berfikir mendalam, keadilan, tanggung jawab dan akuntabilitas, mengambil resiko, disiplin, kegigihan, kreatif, rasa ingin tahu, integritas dan randah hati, dimana karakteristik tersebut dapat dilihat dari sikap dalam memberikan asuhan keperawatan dari keterlibatan, kedewasaan untuk mengontrol emosi dan inovas Berfikir kritis menjadi bagian yang tak terpisahkan dari asuhan keperawatan yang dilakukan oleh perawat. Berfikir kritis penting dilakukan sebelum mengambil keputusan dalam asuhan keperawatan karena berfikir kritis dalam keperawatan merupakan keterampilan berfikir perawat untuk menguji berbagai alasan secara rasional sebelum mengambil keputusan dalam asuhan keperawatan

Salah satu kemampuan berpikir yang termasuk ke dalam kemampuan berpikir tingkat tinggi adalah kemampuan berpikir kritis. Berpikir kiritis berbeda dengan berpikir biasa atau berpikir rutin. Berpikir kritis merupakan proses berpikir intelektual di mana pemikir dengan sengaja menilai kualitas pemikirannya, pemikir menggunakan pemikiran yang reflektif, independen, jernih dan rasional 
Faktor-faktor lainnya yang dapat juga mempengaruhi kemampuan seseorang dalam berpikir kritis adalah kondisi fisik seseorang, keyakinan diri/ motivasi, merasa kecemasan, kebiasaan atau rutinitas yang dikerjakan, perkembangan intelektual, konsistensi atau ketetapan, perasaan atau emosi, dan pengalaman yang biasa rutin dilakukan sewaktu bekerja

Faktor yang mempengaruhi berfikir kritis Faktor yang mempengaruhi berfikir kritis antara lain: Kondisi fisik, kondsi yang lemah tidak mampu bereaksi terhadap respons yang ada.

1. Keyakinan diri/ motivasi,merupakan upaya untuk menimbulkan ransangan, dorongan, atau pun pembangkit tenaga seseorang agar mau berbuat atau melaksanakan sesuatu / memperlihkan prilaku tertentu yang telah direncanakan untuk mencapai tujuan yang ditetapkan.

2. Kecemasan,Dapat mengganggu kesehatan sehingga dapat membatasi seseorang dalam berfikir.

3. Perkembangan intelektual,setiap orang berbeda sesuai dengan usia dan tingkat perkembangannya. Semakain cerdasa seseorang akan semakin kritis

Mengembangkan Cara Berpikir Kritis Terhadap

Mencari pernyataan atau pertanyaan yang jelas artinya atau maksudnya, mencari alasan atas suatu pernyataan, menggunakan dan menyebutkan sumber yang dapat dipercaya, mempertimbangkan situasi secara menyeluruh, berusaha relevan dengan pokok pembicaraan, berusaha mengingat pertimbangan awal atau dasar, mencari alternatif-alternatif, bersifat terbuka, mengambil posisi (atau mengubah posisi) apabila bukti-bukti dan alasan-alasan sudah cukup baginya untuk menentukan posisinya, mencari ketepatan seteliti-telitinya, berurusan dengan bagian-bagian secara berurutan hingga mencapai seluruh keseluruhan yang kompleks, menggunakan kemampuan atau keterampilan kritisnya sendiri, peka terhadap perasaan, tingkat pengetahuan dan tingkat kerumitan berpikir orang lain, menggunakan kemampuan berpikir kritis orang lain.

Kemampuan berpikir kritis yang dikembangkan pada tulisan ini mengacu pada kemampuan berpikir kritis yang dikembangkan oleh Linn \& Gronlund dalam Hadi (2007) yaitu membandingkan, menghubungkan sebab-akibat, memberikan alasan, meringkas, menyimpulkan, berpendapat, mengelompokkan, menciptakan, menerapkan, menganalisis, mensintesis, dan mengevaluasi.

Kemampuan berpikir kritis dapat ditingkatkan melalui latihan. Berikut ini diberikan delapan langkah yang dapat membantu keperawatan atau orang yang ingin meningkatkan kemampuannya dalam berpikir kritis, yaitu : 
1. menentukan masalah atau isu nyata, proyek, atau keputusan yang betul-betul dipertimbangkan untuk dikritisi

2. menentukan poin-poin yang menjadi pandangan

3. memberikan alasan mengapa poin-poin itu dipertimbangkan untuk dikritisi

4. membuat asumsi-asumsi yang diperlukan

5. bahasa yang digunakan harus jelas

6. membuat alasan yang mendasari dalam fakta-fakta yang meyakinkan

7. mengajukan kesimpulan

8. menentukan implikasi dari kesimpulan tersebut.

Lebih lanjut dijelaskan karakteristik dari berpikir kritis menurut Wade dalam Setiawan (2005) adalah menjawab pertanyaan, merumuskan masalah, meneliti fakta-fakta, menganalisis asumsi dan kesalahan, menghindari alasan-alasan yang emasional, menghindari penyederhanaan yang berlebihan, memikirkan intepretasi lain, dan mentoleransi arti ganda. Kemampuan berpikir terutama kemampuan berpikir kritis dan kreatif sangat diperlukan dalam mengajarkan pemecahan masalah pada siswa, karena salah satu indikasi adanya transfer belajar adalah kemampuan menggunakan informasi dan ketrampilan dalam memecahkan masalah. Melalui pemecahan masalah-masalah itu siswa dilatih berpikir kritis melalui latihan. Kesulitan yang umumnya ditemukan pada siswa dalam memecahkan masalah adalah dalam hal memperjelas masalah atau merumuskan masalah yang akan dipecahkan

Penutup:Hasil dari saya membaca jurnal menunjukkan ada hubungan antara kompetensi dengan kemampuan berpikir kritis sedangkan jenis kelamin, umur, tingkat pendidikan, lama bekerja, kepemilikan sertifikat, kecerdasan emosional, cemas dan motivasi tidak mempunyai hubungan dengan kemampuan berpikir kritis. Berdasarkan hasil tersebut diharapkan upaya meningkatkan kemampuan berpikir kritis mengadopsi pola penggunaan pembelajaran yang lebih menekankan kepada diskusi kasus, ronde bersama, dan pendekatan kasus untuk mengembangkan kemampuan klinis dan kemampuan berpikir kritis

Asuhan keperawatan diberikan atas dasar ketidaktahuan,ketidakmampuan dan ketidakmauan pasien dalam memenuhi kebutuhan dasarnya. Perawat dalam memenuhi secara 
komprehensif, menggunakan ketrampilan kritis dan profesional sehingga pelananan yang diberikan bermutu bagi pasien maupun perawat sendiri.

Metode pembelajaran yang dapat berpengaruh terhadap kemampuan berpikir kritis dan kepercayaan diri mahasiswa keperawatan diantaranya adalah konferensi klinis, simulasi, demonstrasi model, peta konsep dan ronde keperawatan, oleh karena itu pembimbing klinik harus mengetahui dengan baik metode pembelajaran yang akan digunakan, agar dapat memilih metode pembelajaran yang tepat dalam pembimbingan khususnya di lingkungan klinik.

\section{Daftar pustaka :}

1. Simamora, R. H. (2019). Menjadi perawat yang: ClH'HUY. Surakarta: Kekata Publisher.

2. Simamora, R. H. (2005). Hubungan Persepsi Perawat Pelaksana Terhadap Penerapan Fungsi Pengorganisasian Yang Dilakukan Oleh Kepala Ruangan Dengan Kinerjanya Diruang Rawat Inap RSUD Koja Jakarta Utara (Doctoral dissertation, Tesis FIK UI, Tidak dipublikasikan).

3. Bambang Sudono DS Dhani Setya A Rif Atiningtyas H. 2017. GAMBARAN KEMAMPUAN BERPIKIR KRITIS PERAWAT PRIMER DALAM PELAKSANAAN ASUHAN KEPERAWATAN DI RUMAH SAKIT ISLAM SURAKARTA.Jurnal IImu Keperawatan. Vol .3,No.1, Hal 81-83

4. Syafrisar Meri Agritubella. 2018. KENYAMANAN DAN KEPUASAN PASIEN DALAM PROSES INTERAKSI PELAYANAN KEPERAWATAN DI RSUD PETALA BUMI. Jurnal indurance. Vol.3, No.1, HAL

5. Yanti Sutriyanti \&, Mulyadi.2019. Analisis Faktor-Faktor yang Mempengaruhi Penerapan Berpikir Kritis Perawat dalam Melaksanakan Asuhan Keperawatan di Rumah Sakit. Jurnal Keperawatan Raflesia, Volume 1 Nomor 1,Hal 21-23

6. Indriatie.2013. BERFIKIR KRITIS DALAM PROSES KEPERAWATAN CRITICAL THINKING IN THE NURSING PROCESS. Jurnal keperawatan. VOL. VI NO. 2. Hal 90-93

7. Try Ayu Patmawati,Ariyanti Saleh \&, Syahrul Syahrul.2018. Efektifitas Metode Pembelajaran Klinik Terhadap Kemampuan Berpikir Kritis dan Kepercayaan Diri Mahasiswa Keperawatan : A Literature Review. Jurnal Keperawatan Muhammadiyah. Vol.3,No 2,Hal 89-92

8. Octy Rezkya Ramadhiani \&, Tatiana Siregar.2019. Hubungan Berpikir Kritis dengan Kepedulian (Caring) Perawat dalam Melaksanakan Asuhan Keperawatan di RSUDKota Depok. jurnal kedokteran dan kesehatan.Vol.15, No.2,Hal 149 
9. Achmad Rif'at, Elly Nurachmah \&, Yustan Azidin. 2019. Pengalaman Penerapan Kemampuan Berpikir Kritis Perawat Saat Memberikan Asuhan Keperawatan Pada Bayi Berat Lahir Rendah Di RSUD Dr. H. Moch. Ansari Saleh Banjarmasin. Jurnal Kebidanan dan Keperawatan . Vol.10, No. 1.Hal28-29

10. Ilfa Khairina, Hema Malini \& Emil Huriani.2018. FAKTOR-FAKTOR YANG BERHUBUNGAN DENGAN PENGAMBILAN KEPUTUSAN PERAWAT DALAM KETEPATAN TRIASE DI KOTA PADANG. Indonesian Journal for Health Sciences.Vol.02, No.01.Hal 5-6

11. Kiki Deniati, Ria Anugrahwati \& Tini Suminarti.2018. PENGARUH BERFIKIR KRITIS TERHADAP KEMAMPUAN PERAWAT PELAKSANA DALAM MELAKUKAN ASUHAN KEPERAWATAN DI RUMAH SAKIT HERMINA BEKASI TAHUN 2016. Jurnal Kesehatan Holistik (The Journal of Holistic Healthcare), Volume 12, No.1, Hal 21-22

12. Ida Yuli Angkotasan, Paulus Subiyanto, Nuryeti Syarifah, \& Nurma Angkotasan. 2015. HUBUNGAN KEMAMPUAN BERPIKIR KRITIS DENGAN PRESTASI BELAJAR MATA KULIAH KEPERAWATAN MEDIKAL BEDAH II MAHASISWA SEMESTER VII PROGRAM STUDI ILMU KEPERAWATAN (S-1) SEKOLAH TINGGI ILMU KESEHATAN WIRA HUSADA YOGYAKARTA TAHUN AKADEMIK 2012-2013. jurnal pendidikan.Vol.13,No.02,Hal 272 